JURNAL Midwifery Update (MU)

http://jurnalmu.poltekkes-mataram.ac.id/index.php/jurnalmu

e-ISSN: 2684-8511 (Online)

\title{
EFEKTIFITAS KETERAMPILAN PENGISIAN PARTOGRAF DENGAN MENGGUNKAN MEDIA APLIKASI SPART DENGAN LEMBAR PARTOGRAF KONVENSIONAL PADA MAHASISWA PRODI DIV KEBIDANAN DI POLTEKKES KEMENKES MATARAM
}

Baiq Eka Putri Saudia

Program Studi D-IV Kebidanan Politeknik Kesehatan Kemenkes Mataram

\begin{abstract}
Abstrak
Aplikasi Spart ( Smart Partograf) terinspirasi dari form partograf manual yang saat ini sering digunakan di semua instansi kesehatan, Dengan mengimplementasikan form partograf manual kedalam bentuk aplikasi yang dapat memudahkan pencatatan kemajuan kala satu fase aktif, Kesejahteraan Ibu dan janin serta mengambil keputusan klinik secara cepat dan tepat. Untuk mengetahui perbandingan penggunaan aplikasi Spart dengan Lembar partograf konvensional terhadap keterampilan sebagai alat bantu media belajar mahasiswa..penelitian ini menggunakan metode penelitian quasi eksperimen, populasi dalam penelitian semua mahasiswa jurusan D-IV Kebidanan, dan sampel dalam penelitian ini adalah mahsisiwa tingkat III semester VI sebanyak 42 Sampel., dari 42 sampel dibagi menjadi 2 kelompok yaitu kelompok media yang menggunkan aplikasi Spart dan Kelompok yang menggunkan lembar partograf konvensional, media belajar yang menggunkan aplikasi spart sebanyak 21 sampel dengan kategori mahir ada $21(50 \%)$ sampel dan katagori tidak mahir ada $0(0 \%)$ sampel sedangkan media belajar yang menggunkan lembar konvensional sebanyak 21 sampel dengan kategori mahir ada $6(14,3 \%)$ sampel dan katagori tidak mahir ada 15 (35,7\%) sampel. Media belajar menggunkan aplikasi spart lebih efektif dari pada menggunkan lembar partograf konvensional serta bisa di jadikan media bantu belajar mahasiswa jurusan kebidanan, adapun saran peneliti, aplikai spart tetap digunkan di lingkungan kampus terutama di poltekes kemenkes mataram.
\end{abstract}

Kata Kunci : Keterampilan ; Aplikasi Spart ; Lembar Partograf Konvensional

\section{DIFFERENCES IN PARTOGRAPH FILLING SKILLS USING SPART APPLICATION MEDIA WITH CONVENTIONAL PARTOGRAPH SHEETS IN MIDWIFERY DIV STUDENTS IN POLTEKKES KEMENKES MATARAM}

Abstract

The Spart (Smart Partograph) application is inspired by the manual partograph form that is currently often used in all health agencies. By implementing the manual partograph form into an application that can facilitate recording progress during an active phase, the welfare of the mother and the fetus and making clinical decisions quick and precise. To find out the 
comparison of the use of the Spart application with conventional partograph sheets on skills as a learning media tool for students ... this study used a quasi-experimental research method, the population in the study were all students majoring in D-IV Midwifery, and the sample in this study were students of grade III semester VI. 42 samples., of the 42 samples divided into 2 groups, namely the media group that used the Spart application and the group that used the conventional partograph sheet, 21 samples of learning media that used the Spart application with the advanced category, there were $21(50 \%)$ samples and the category was not proficient. There are $0(0 \%)$ samples while the learning media that uses conventional sheets are 21 samples with the advanced category there are $6(14.3 \%)$ samples and the nonproficient category is $15(35.7 \%)$ samples. Conclusion: Learning media using the spart application is more effective than using conventional partograph sheets and can be used as learning aids for students majoring in midwifery, as for the advice of researchers, the spart application is still used in the campus environment, especially in Poltekkes Kemenkes Mataram.

Keywords: Skills; Spart Application; Conventional Partograph Sheet

\section{Pendahuluan}

Penggunaan teknologi pembelajaran semakin kuat pengaruhnya seiring dengan perkembangan teknologi informasi dan komunikasi (TIK) yang telah merambah kehidupan masyarakat. Pembelajaran menggunakan TIK sering disebut dengan elearning. ${ }^{8}$

Penggunaan internet dan web dapat memberikan kontribusi yang positip terhadap kegiatan akademik mahasiswa untuk menggali informasi dan ilmu pengetahuan dalam mata kuliah yang menjadi bidang kemampuannya. Melalui penggunaan internet dan web, mahasiswaakan selalu siap mempelajari ilmu pengetahuan. (humanware)..$^{8,12}$

Partograf merupakan alat bantu untuk membuat keputusan klinik, memantau, mengevaluasi dan menatalaksana persalinan. Partograf dapat digunakan untuk mendeteksi masalah dan penyulit sesegera mungkin, menatalaksana masalah dan merujuk ibu dalam kondisi gawatdarurat. ${ }^{3}$

Namun sebagian besar kendala mahasiswa dalam pengisian partograf secara manual ini memiliki ketelitian yang kurang bagi mahasiwa yang baru mempelajari partograf. Oleh karena itu diperlukan alat bantu yang lebih menunjang dan memadai mahasiswa untuk memantau kemajuan persalinan dalam bentuk aplikasi berbasis website yang dapat diakses. 
Aplikasi pencatatan partograf (Spart) ini akan mempermudah dan mempercepat penolong persalinan dalam pembuatan atau mengisi partograf tersebut, dengan adanya aplikasi ini pula partograf yang dihasilkanpun akan lebih teliti dan mudah untuk dibaca dibandingkan dengan ditulis tangan.

Spart merupakan alat bantu yang di buat dalam bentuk aplikasi berbasis website. Hasil pembuatan aplikasi Spart (Smart Partograf) bertujuan untuk memudahkan mahasiswa dalam melakukan tugas pencatatan kemajuan kala satu fase aktif, kesejahteraan ibu dan janin serta mengambil keputusan klinik secara cepat.

\section{Metode Penelitian}

Penelitian ini menggunakan Metode penelitian quasi eksperimen. metode penelitian eksperimen dapat diartikan sebagai metode penelitian yang digunakan untuk mencari pengaruh perlakuan tertentu terhadap yang lain dalam kondisi yang terkendalikan. ${ }^{15}$ Populasi dalam penelitian ini adalah Mahasiswi Jurusan D-IV Kebidanan. Dalam penelitian ini, sampelnya adalah mahasisiwi tingkat III semester VI dengan jumlah 42 sampel dengan di bagi menjadi 2 kelompok yaitu 21 sampel menggunkan media belajar dengan Aplikasi Spart dan 21 sampel menggunkan media belajar dengan Partograf Konfensional

Sampelnya diambil secara purposive sampling. Purposive Sampling merupakan teknik sampling yang termasuk dalam Nonprobability Sampling. Purposive Sampling adalah teknik penentuan sampel berdasarkan pertimbangan tertentu. ${ }^{15}$

Dalam penelitian ini yang menjadi variabel independennya adalah aplikasi spart dan lemar partograf konvensional dan variabel dependenya adalah keterampilan penelitian ini menggunakan data primer yang dilakukan secara langsung oleh peneliti untuk mengolah data penelitian di poltekes kemenkes mataram jurusan kebidanan . Data dianalisis secara univariat dengan tabel distribusi frekuensi serta analisis bivariat dalam menguji hipotesi menggunakan uji chi-square $\left(\mathrm{x}^{2}\right)$, dengan tingkat kemaknaan $\mathrm{p}=0,05$ dan confidance interval (95\%). 


\section{Hasil Dan Pembahasan}

1. Media belajar menggunakan aplikasi spart dan lembar partograf konvensional

Tabel 1. Distribusi media belajar menggunkan Aplikasi Spart dan lembar partograf konfensional

\begin{tabular}{lllc}
\hline No & Media Belajar & N & \% \\
\hline 1. & Aplikasi Spart & 21 & $50 \%$ \\
2. & Partograf konfensional & 21 & $50 \%$ \\
\hline & Total & 42 & 100,0
\end{tabular}

Dari Tabel diatas terlihat bahwa dari 42 orang sampel, media belajar menggunakan aplikasi spart sebanyak $21(50 \%)$ sampel sama dengan partograf konfensional sebanyak 21 (50\%) sampel.

\section{Perbandingan Keterampilan pengisian menggunakan media belajar Aplikasi Spart dan lembar partograf konfensional}

Tabel 2. Distribusi keterampilan pengisian menggunakan media belajar Aplikasi Spart dan lembar partograf Konfensional

\begin{tabular}{ccccc}
\hline Keterangan & \multicolumn{2}{c}{ Aplikasi Spart } & \multicolumn{2}{c}{$\begin{array}{c}\text { Partograf } \\
\text { Konfensional }\end{array}$} \\
\cline { 2 - 5 } & $\mathbf{n}$ & $\%$ & $\mathrm{n}$ & $\%$ \\
\hline Mahir & $\mathbf{2 1}$ & $\mathbf{1 0 0 \%}$ & $\mathbf{6}$ & $\mathbf{2 8 , 6 \%}$ \\
\hline Tidak Mahir & $\mathbf{0}$ & $\mathbf{0 \%}$ & 15 & $\mathbf{7 1 , 4 \%}$ \\
\hline
\end{tabular}

Dari Tabel diatas terlihat bahwa dari 21 sampel, Keterampilan pengisian Aplikasi Spart dengan kategori Mahir sebanyak 21 (100 \%) , lebih banyak dibandingkan dengan Keterampilan pengisian Aplikasi Spart dengan katagori Tidak Mahir sebanyak 0 (0\%), sedangkan untuk 21 sampel, Keterampilan pengisian partograf konfensional dengan kategori Mahir sebanyak 6 (28,6\%), lebih sedikit dibandingkan dengan Keterampilan pengisian partograf konfensional dengan katagori Tidak Mahir sebanyak 15 ( 71,4\%) . 


\section{Mengidentifikasi media pembelajaran dengan Aplikasi Spart dan lembar Partogarf Konfensional.}

Dari hasil penelitian terlihat bahwa dari 42 sampel yang menggunakan media belajar dengan aplikasi spart dengan katagori mahir sebanyak 21 (100\%) sampel dan tidak mahir sebanyak $0(0 \%)$ sampel sedangkan menggunkan media belajar partograf konvensional dengan katagori mahir sebanyak $6(28,6 \%)$ sampel dan tidak mahir sebanyak 15 (71,4\%) sampel.

Kepatuhan adalah mematuhi dan mentaati peraturan standar asuhan persalinan, kecendrungan bidan untuk bertindak dalam melakukan kegiatan pencatatan partgrafyang menjadi standardalam memberikan asuhan persalinan. ${ }^{1}$

\section{Menganalisa Perbandingan Keterampilan Pengisian Partograf Dengan Spart Berbasis Web Dengan Partograf Konvensional}

Hasil perbandingnya didapatkan hasil $O R$ nya yaitu 3,5 itu menandakan 3,5 lebih efektif menggunakan media belajar dengan keterampilan pengisian Aplikasi Spart dari pada menggunakan media belajar dengan keterampilan partograf konfensional.

Spart (Smart Partograf) adalah aplikasi pencatat kemajuan persalinan, kesejahteraan Ibu dan janin serta mengambil keputusan klinik, yang lebih efisien digunakan dari pada menggunakan form manual, Aplikasi Spart dirancang dari hasil pengimplementasian form partograf manual, ditujukan supaya proses pengisian partograf menjadi lebih mudah dan efisien, sehingga proses pencatatan kemajuan kala satu fase aktif, Kesejahteraan Ibu dan janin serta mengambil keputusan klinik. ${ }^{5}$

\section{Kesimpulan}

Berdasarkan hasil analisis dan pembahasan diatas dapat disimpulkan sebagai berikut:

1. Dari hasil penelitian menggunkan media belajar Aplikasi Spart mayoritas mahir sebanyak $21(100 \%)$ sampel, menggunkan media belajar partograf konvensional mayoritas tidak mahir sebanyak 15 (71,4\%) sampel.

2. Dari Hasil perbandingnya disimpulkan bahwa mahasiswa yang menggunakan spart 3,5 lebih mahir menggunakan Aplikasi Spart dari pada menggunakan partograf konfensional. 


\section{Daftar Pustaka}

1. APN, 2011. Asuhan Persalinan Normal Dan Inisiasi Menyusui Dini, Jakarta ; JNPK-KR ; Jakarta

2. Depdiknas, 2015. Pendektan Keterampilan. Jakarta : PT. Preenhalindo

3. Depkes, 2014. Laporan Hasil Riset Kesehatan Dasar Indonesia. Jakarta : Badan Penelitian dan Pengembangan Kesehatan Depkes RI.

4. Hidayah, 2011. Metodelogi Penelitian Kesehatan. Surabaya: Health Books Publishing

5. Miarso, Yusufhadi. 2014. Menyemai Benih Teknologi Pendidikan. Jakarta : Kencana

6. Nawawi, Hadari. 2014. Penelitian Terapan. Yogjakarta; Gadjah Mada University Press

7. Notoatmodjo, 2015. Metodologi Penelitian. Bandung : PT. Rineka Cipta

8. Nurchaili, 2016. Menumbuhkan Budaya Literasi Melalui Buku Digital. Banda Aceh (Artikel). Man Darussalam Kabupaten Aceh Besar.

9. Oetomo, Priyogutomo.2014. Belajar Dan Pembelajaran. Yogyakarta : Graha Ilmu

10. Priwirohardjo, Sarwono. 2012. Ilmu Kebidanan. Jakarta: PT. Bina Pustaka Sarwono Prawirohardjo.

11. Profil Poltekkes Kemenkes Mataram, 2017/2018, Mataram

12. Rahmat Setiadi, Akhril Agus. 2012. Pembelajaran Berbasis Teknologi Informasi dan Komunikasi. Bandung : Alfa Beta CV. Bandung

13. Saifudin AB. 2012. Buku Acuan Nasional Pelayanan Kesehatan Maternal dan Neonatal. Jakarta; PNPKKR-POGI

14. Santi Wahyuni. 2012. Pemantauan Kesejahteraan Janin Selama Kehamilan. URL: $\quad$ http://www.stikku.ac.id/wp-content/ uploads/2011/02/Partograf.pdf. (Sitasi: 10 April 2014, pukul 20.10 wita).

15. Sugiyono, 2014. Metode Penelitian Kuantitatif dan Kualitatif. Bandung : Alfa 